This item was submitted to Loughborough's Research Repository by the author.

Items in Figshare are protected by copyright, with all rights reserved, unless otherwise indicated.

\title{
Heretical constructions of anarchist utopianism
}

PLEASE CITE THE PUBLISHED VERSION

https://doi.org/10.1080/01916599.2020.1761646

PUBLISHER

Routledge

VERSION

AM (Accepted Manuscript)

PUBLISHER STATEMENT

This is an Accepted Manuscript of an article published by Taylor \& Francis in History of European Ideas on 12 May 2020, available online: http://www.tandfonline.com/10.1080/01916599.2020.1761646.

\section{LICENCE}

CC BY-NC-ND 4.0

\section{REPOSITORY RECORD}

Kinna, Ruth. 2020. "Heretical Constructions of Anarchist Utopianism”. Loughborough University. https://hdl.handle.net/2134/9896444.v1. 
Ruth Kinna

School of Social Sciences and Humanities

Loughborough University

LE11 3TU

01509223651

r.e.kinna@lboro.ac.uk 


\title{
Heretical Constructions Of Anarchist Utopianism ${ }^{1}$
}

\author{
Ruth Kinna
}

Orcid 0000-0002-1920-464X

\begin{abstract}
This paper examines a relationship between heresy and utopianism forged in nineteenth- and early twentieth-century socialist histories to reveal a significant and pervasive fault-line in the ideological construction of anarchism. I look at Marxist narratives which trace the lineages of socialism to medieval religious dissent and show how the sympathetic assessment of European heretical movements was moulded by a critique of utopianism, understood as the rejection of materialist 'science'. I argue that strands of this narrative have been woven into anarchism by looking at three accounts: E.V. Zenker's Anarchism (1897), James Joll's The Anarchists (1964/1979) and Saul Newman's From Bakunin to Lacan (2001). Their dominant theme is that anarchism promises the transformation of corrupted nature, typically achieved though ecstatic violence, cataclysmic revolution and future perfection. I describe this Millenarian anarchism as a 'straw man' but rather than jettison 'heresy' as an investigative tool, I refer to a conception of heresy as choosing to present an alternative account. Using Martin Buber's analysis of utopianism in Paths in Utopia (1949) and Michael Bakunin's critique of political theology, I pair utopianism with the rejection of perfection and heresy with faith. This reframing of heresy corrects a deep-rooted, long-standing distortion of anarchist ideas.
\end{abstract}

\footnotetext{
${ }^{1}$ I am grateful to Alexandre Christoyannopoulos, Robert Knight and especially Anthony Fiscella for comments on earlier drafts of this paper.
} 
Keywords: anarchism, utopianism, heretical politics, Michael Bakunin, Martin Buber, antitheologism. 


\section{Introduction}

Heresy is a troubling and complex term: troubling because it is usually associated with denunciation, suspicion and corrective punishment and complex because, while 'heresy' often connotes fear and injustice, such as that depicted in Arthur Miller's The Crucible, it has multiple meanings. Standard dictionaries variously define heresy as the rejection of scripture, especially Christian doctrine or faith; the denial of orthodoxy, with or without opprobrium; sectarianism; heterodox private opinion, unmediated by fundamental religious truth or authority. ${ }^{2}$ This diversity is reflected in intellectual debate, too. The evolutionist and agnostic T.H. Huxley argued that the possibility of social advance depended on the controversy that heresy stirred. Heresies were 'new truths' initially rejected as profane and subsequently absorbed 'as superstitions' ${ }^{3}$ The essayist and fellow agnostic Robert Ingersoll defended heresy in similar terms but associated it with dissent. Rooted in historical demands for compliance, namely the attempt 'to force all people to hold the same religious opinions', heresy challenged dominant power relations. It is 'what the minority believe; it is the name given by the powerful to the doctrine of the weak'. ${ }^{4}$ Ananda Coomaraswamy reformulated Samuel Taylor Coleridge's view of heresy as 'a principle or opinion taken up by the will for the will's sake, as a proof or pledge to itself of its own power of self-determination, independent of all other motives ${ }^{, 5}$. In a discussion of religion and toleration Coomaraswamy argued: 'The word "heresy" means choice, the having opinions of one's own, and thinking

\footnotetext{
${ }^{2}$ See the multiple entries in The Concise Oxford dictionary of current English, adapted by H.W. Fowler and F.G. Fowler, 7th impression, (Oxford: Clarendon Press, 1919); Webster's 1913 American English Dictionary, https://www.websters1913.com/ (accessed April 11, 2019).

3 'History warns us that it is the customary fate of new truths to begin as heresies and to end as supertitions', Henrietta A. Huxley Aphorisms and Reflections From the Works of T.H. Huxley (London: Macmillan, 1907) https://mathcs.clarku.edu/huxley/Book/Aphor.html (accessed April 11, 2019).

${ }^{4}$ Robert Ingersoll, 'Heretics and Heresies', in The Gods and Other Lectures (Peoria, Illinois: Knight and Leonard, 1877), 209.

${ }^{5}$ Coleridge's comments appear in Samuel Taylor Coleridge Complete Works, ed. W.G.T.Shedd, vol. II The

Friend, (New York: Harper and Brothers, 1884), 390.
} 
what we like to think: we can only grasp its real meaning today, when "thinking for oneself" is so highly recommended ... if we realize that the modern equivalent of heresy is "treason.",6

Building on the interplay between subjugation and the possibility of contesting power, contemporary political theorists have used heresy to signal deviation from moral or epistemic norms and initiate projects for intellectual liberation. John Grey employs to heresy to challenge secular humanism, the predominant 'faith' of the twentieth century which, he argues, still permeates in our current times. ${ }^{7}$ Peter Lamborne Wilson uses heresy to denote his rejection of the master-slave dichotomy and refusal to align with either oppressors or oppressed. More specifically, heresy describes a form of emancipatory eclecticism: the heretic, Wilson argues, embraces all forms of religion and remains free. ${ }^{8}$ Also identifying the constructive potential of heresy, Anthony Bogues follows convention to define heresy as deviation from orthodoxy to show, against convention, how black intellectuals have overturned the political and social categories that define white orthodoxy. ${ }^{9}$

I examine an account of heresy in socialist thought to probe the construction of anarchism. I borrow Jon Parkin's formulation of the 'straw man fallacy' to argue that a narrative about heretics and anarchists helps explains the construction of a crude ideological model. ${ }^{10}$ I show how anarchists have responded to it also by embracing heresy, as Bogues might recommend. In attempting to rescue anarchist heretical thought from the orthodoxy that treats them negatively as latter day 'heretics', I accept that anarchists often failed to challenge repressive conventions. Some of the most celebrated nineteenth century activists readily adopted misogynistic, anti-Seminitic and racist tropes and often remained silent about forms of domination affecting marginalised groups: in Bogues terms, they were not always

\footnotetext{
${ }^{6}$ Ananda K. Coomaraswamy, 'Paths That Lead to the Same Summit', in The Bugbear of Literacy (London: Denis Dobson, 1943) 49.

${ }^{7}$ John Gray, Heresies: Against Progress and Other Illusions (London: Granta 2004).

${ }^{8}$ Peter Lamborn Wilson, Heresies, (Brooklyn, NY: Autonomedia, 2016), 9; 45.

9 Anthony Bogues, Black Heretics, Black Prophets: Radical Political Intellectuals (London: Routledge, 2003), 13 .

${ }^{10}$ Jon Parkin, 'Straw Men and Political Philosophy: The Case of Hobbes', Political Studies 59 (2011): 564-579.
} 
thoroughgoing heretics. Yet I concentrate on the construction of the model because I want to argue that the critical politics anarchists defended is more malleable to the projects that modern theorists advance than the straw man thesis suggests. The argument has three steps: Part one adapts Clare Hemmings' storytelling method to contrast two alternative accounts of heresy in nineteenth century social democracy. ${ }^{11}$ Whereas Hemmings reveals the antagonistic reductions fuelled by oppositional narratives, using citation data to identify polarities within feminism, I consider how a concept 'heresy' was alternatively subsumed within the logic of Marxist utopianism and reassessed by critics to question that orthodoxy. The second part explores the theoretical legacy of this coupling of heresy with utopianism in histories of anarchism, outlining the main features of the straw man. Taking full advantage of the complexity of the term, in the third part I present an anarchist defence of heresy and utopianism to contest the construction of anarchism that Marxist heretical utopianism undergirds.

\section{Heresy and utopianism in socialist histories}

Nineteenth-century socialism contains at least two stories about heresy. Utopianism is central to both. The first emerged from the study of pre-socialist dissenting movements, principally, but not exclusively, medieval Christian heresies. For Karl Kautksy, 'the chief architect and ... embodiment of Marxist orthodoxy', ${ }^{12}$ 'heretical communists' like the sixteenth-century radical preacher Thomas Müntzer were inspirational figures whose successes and failures provided important lessons for the progress of modern socialism. ${ }^{13}$ Yet, as will be seen, the

\footnotetext{
${ }^{11}$ Clare Hemmings, 'Telling Feminist Stories', Feminist Theory 62 no. 2 (2005): 115-139

${ }^{12}$ Leszek Kolakowski, Main Currents of Marxism: Its Origins, Growth and Dissolution vol. 2 The Golden Age, trans. P.S. Falla, (1978; repr. 1985 Oxford: Oxford University Press): 31.

${ }^{13}$ Karl Kautsky, Communism in Central Europe in the Time of the Reformation, trans. J.L. \& E.G. Mulliken (2017; facsimile London: Fisher and Unwin, 1897): ch. 1. The English-language title is an abridged version of the 1895 German-language book (The Forerunners of Socialism). For a discussion see Paul Blackledge, 'Karl Kautsky and Marxist Historiography', Science and Society 70 no. 3 (2006): 337-59.
} 
notion of heresy that Müntzer and others were said to embody took its meaning from an associated conception of utopianism. ${ }^{14}$

As David Leopold argues, Marx and Engels distinguished between utopias chronologically and judged them textually. Marx and Engels's view that 'Critical-Utopian Socialism and Communism bears an inverse relation to historical development' summed up the chronological distinction. ${ }^{15}$ The textual interpretation sought to promote utopian critique while rejecting intentional community experiments and the advancement of fantastical visions or ideals. ${ }^{16}$ Engels' popularisation of 'scientific socialism' after Marx's death introduced a harder conceptual distinction to utopian chronology. In later formulations utopianism was associated with the stubborn denial of materialist history and the rejection of the revolutionary strategies that Marxist social democracy prescribed. Those who continued to play with speculative visions after Marx's discovery of scientific socialism were foolish, misguided dreamers and often reformists, too. Whether or not they continued to believe, as the Utopians had done, that change could be achieved gradually and without struggle, their utopianism was not just flawed, it amounted to wilful deception. ${ }^{17}$

Heretics stood in an interesting position in respect of Engels' division, for they were at once genuine revolutionaries but also visionaries and preachers. Accordingly, materialist history highlighted significant continuities of strategy between old heresies and modern socialism but equally exposed a gulf in their social outlooks. In brief, socialists continued

\footnotetext{
${ }^{14}$ Karl Marx and Friedrick Engels, The Communist Manifesto, trans. Samuel Moore (1888; repr. Moscow: Progress Publishers, 1986): 64-7.

${ }^{15}$ Marx and Engels, Communist Manifesto, 65.

${ }^{16}$ Following David Leopold's account of Marxist utopianism, 'The structure of Marx and Engels' Considered Account of Utopian Socialism', History of Political Thought 26 (2005): 443-466; 'Socialism and (the rejection of) utopia, Journal of Political Ideologies 12 no. 3 (2007): 219-237.

${ }^{17}$ Frederick Engels, Anti-Dühring, (1894; repr. Peking: Foreign Languages Press, 1976), 341-43. The book was originally published in German in 1877-78. The critique of utopianism was disseminated widely by the publication of the pamphlet Socialism: Utopian and Scientific which first appeared in French in 1880. Engels estimated that it was translated into more languages than the Communist Manifesto and that by 1892, when the English edition was issued, 20,000 copies had been sold in Germany alone. Frederick Engels, Socialism: Utopian and Scientific, trans. Edward Aveling (1892; repr. London: George Allen \& Unwin, 1950). See also George Plechanoff, Anarchism and Socialism trans. Eleanor Marx Aveling (Chicago: George H. Kerr, n.d.).
} 
heretical traditions of struggle but rejected the ideas of perfection that drove heresy and so also attacked the 'new social Gospel' that Utopians had integrated into socialism. ${ }^{18}$

The interest in heresy can be explained as part of a general effort that European intellectuals made to contest anti-socialist accusations that communism was, as Kautsky put it, 'antagonistic to the existence of man - antagonistic indeed to human nature itself'. ${ }^{19}$ Leading socialists produced a series of histories which, in different ways, attested to socialism's deep roots in radical plebeian politics. William Morris's fictionalised account of the 1381 Peasants' Revolt, The Dream and John Ball $(1888)^{20}$ and Eduard Bernstein's history of Cromwell and the Levellers, Socialism and Democracy in the Great English Revolution $(1895)^{21}$ are two notable examples. In this diverse literature the constancy of the aspiration for liberation from exploitation and oppression is a dominant theme and it drew attention to the distinctiveness of socialist struggle and to the changes in social conditions and consciousness that accompanied the rise of labour and working class activism.

Engels' essay 'On the History of Early Christianity' (1894) contextualised the research, forging a strong association between socialist struggle and Christian religious dissent. Engels described Christianity as 'a movement of oppressed people' a 'religion of slaves and freedmen, of poor people deprived of all rights, of peoples subjugated or dispersed by Rome'. ${ }^{22}$ Like socialism, Christianity preached 'forthcoming salvation from bondage and misery'. And like the socialists, Christians had been 'persecuted and subjected to harassment' for their trouble. Their adherents had been 'ostracised and made the objects of exceptional laws, the ones as enemies of the human race, the others as enemies of the state, enemies of

\footnotetext{
${ }^{18}$ Marx and Engels, Communist Manifesto, 65.

${ }^{19}$ Kautsky, Communism in Central Europe, 2.

${ }^{20}$ William Morris, A Dream of John Ball, Three Works by William Morris, ed. A.L. Morton (1968; repr. London: Lawrence and Wishart, 1986).

${ }^{21}$ Published in English as Cromwell and Communism, trans. H.J. Stenning, (1930; repr., Nottingham: Spokesman Press, 1980).

${ }^{22}$ Frederick Engels, 'On the History of Early Christianity', in Karl Marx and Frederick Engels Collected Works, (repr. London: Lawrence and Wishart, 1990), vol. 27: 447.
} 
religion, the family, the social order'. ${ }^{23}$ Finally, Christianity and socialism were both transformative creeds. Here, however, Engels' added an important qualifier: socialism had been realised through Christianity but Christianity was never really socialist: his view was that Christianity was centrally concerned with the afterlife, whereas socialism's interest lay in the achievement of earthly change. Detecting a temporary shift in the Middle Ages when the movements constituting the radical Reformation sprang into life, Engels noted that the attention given to worldly affairs lessened 'after the German Peasant War' and that it was revived only 'with the worker communists after $1830,{ }^{24}$ Christianity thus remained detached from real-world politics and fixed on matters of 'eternal life after death, in the impending "millennium.",25

Like Engels, Kautsky found lineages of modern socialism in Christianity and in Foundations of Christianity (1908) he presented a materialist account of history to show how the earliest proletarian Christian community had been transformed into the 'world's most powerful machine for mastery and exploitation'. ${ }^{26}$ Jesus, the spokesperson for the messianic groups who organised against Roman enslavement, had 'conquered the world', but not for the proletariat. Indeed, the movement Jesus headed was subjugated and enslaved; the Christian Messiah was Caesar's successor and became a role model for Napoleon.

Kautsky disagreed with Engels' characterisation of medieval revolutionary movements, however, his objection tended to deepen the impression of Engels' thesis. In Kautsky's view the 'most salient feature of the communism' which began to emerge in the twelfth century was the 'antagonism to the Papal power'. ${ }^{27}$ This configuration of power gave it 'an ever-

\footnotetext{
${ }^{23}$ Ibid., 447.

${ }^{24}$ Ibid., 448

${ }^{25}$ Ibid., 448.

${ }^{26}$ Karl Kautsky, Foundations of Christianity, trans. Henry F. Mins, (1953: repr. London: Socialist Resistance, 2008), 199.

${ }^{27}$ Kautsky, Communism in Central Europe, 2.
} 
increasing heretical character, ${ }^{28}$ distinguishing it as non-proletarian. Endorsing a conservative view of heresy, (contrary to dissidents who regarded the Pope and Reformation leaders as heretical), Kautsky argued that 'heretical communism' could have no other character because "the foundations of a new social order of society and government were non-existent'. ${ }^{29}$ Unlike Engels, he thus classified key figures in radical Reformation as millenarians. Even Müntzer, 'the brilliant embodiment of heretical communism' who 'surpassed' his comrades in his 'philosophic conceptions' and his 'talent for organising' fell into this category. ${ }^{30}$ Kautsky's admiring portrait paints Müntzer as a social and political revolutionary not just an ecclesiastical dissident, who forged alliances with mine-workers in Saxony and bravely lead the battle of Frankenhausen in 1525, waging war with a 'vehemence' that was unmatched. Müntzer was an astute political analyst who refused to limit 'his operations to a small community of true believers' and 'appealed to all the revolutionary elements of his time'. Yet for all this, Kautsky argued that he remained a mystic and ascetic. ${ }^{31}$

The view that Kautsky rejected had been put by the Wilhelm Zimmermann, the historian who re-habilitated Müntzer in a history written to inspire 1848ers and which subsequently served as the touchstone for Engels' and Kautsky's work. ${ }^{32}$ Kautsky contested Zimmerman's view that Müntzer's political and religious views were 'ahead of his age and superior to it'. In advancing this view Zimmerman had failed to contextualise properly Müntzer's thought and wrongly set his ideas alongside the work of 'modern thinkers' like Jean-Jacques Rousseau. Had he looked at the 'communistic sects' of the period Zimmerman

\footnotetext{
${ }^{28}$ Ibid., 2.

${ }^{29}$ Ibid., 3 .

${ }^{30}$ Ibid., 109; 154.

${ }^{31}$ Ibid., 110.

${ }^{32}$ Friedrich Engels, The Peasant War in Germany in Karl Marx and Frederick Engels Collected Works, (1875: repr. London: Lawrence and Wishart, 1978), vol. 10: 999-482. On Zimmermann and Müntzer historiography see Abraham Friesen, 'Philippe Melanchthon (1497-1560), Wilhelm Zimmermann (1807-1878) and the Dilemma of Muntzer Historiography', Church History 43 no. 2 (1974): 164-82.
} 
would neither have overegged Müntzer's significance as an organiser and propagandist' nor wrongly concluded that he was " "three centuries in advance of his time",. ${ }^{33}$ Müntzer was not and could not have been.

The judgments that Kautsky and others made about the ideational constraints imposed by material reality were often nuanced. Kautsky's (1888) and Morris's (1893) separate studies of Thomas More's Utopia, estimated More's grasp of impending social development quite differently. ${ }^{34}$ Yet both agreed that material conditions were insurmountable and that More was as much a child his age as Müntzer had been and powerless, therefore, to 'overstep its limits'. ${ }^{35}$ Indeed, Kautsky's treatment of Müntzer historicised heresy in the same way that Marx and Engles' had earlier historicised the Utopians: if 'utopianism' marked a before and after 'science', 'heresy' was the turning point from 'religion' to 'secularism' and from spiritual to worldly affairs. Later Marxist studies of the Reformation sometimes conflated these currents of ideas. Ernest Belfort Bax's 1903 Reformation history delivered an unequivocally anti-utopian message about pre-socialist failure that chimed closely with Kautsky's materialist analysis of heresy. Morris's close comrade and philosopher had distinguished himself as a Marxist critic of one-sided materialism yet Bax's message was that heresy honoured socialism's precursors and utopianism explained their failures. 'Thomas Müntzer, Jan of Leyden, Jan Matthys, and the rest of those who sought the re-vindication of social justice in the early 16 th century' were entirely absorbed by 'visions of a "New Jerusalem," of a divine "Millennial Kingdom" brought about by the dispensation of a

\footnotetext{
${ }^{33}$ Kautsky, Communism in Central Europe, 109.

${ }^{34}$ Karl Kautsky, Thomas More and his Utopia (London: Lawrence \& Wishart, 1979), 2. For a discussion see Peter Schwartz, 'Imagining Socialism: Karl Kautsky and Thomas More', Journal of Comparative Sociology 30 (1989): 44-55; William Morris, 'Foreword to Thomas More's Utopia', in William Morris: Artist, Writer, Socialist ed. May Morris (Oxford: Basil Blackwell, 1936), 289

${ }^{35}$ Kautsky, Thomas More, 44-55.
} 
supernatural Providence'. But they were 'the forerunners of Modern Socialism' and as such, they deserved 'passing tribute of recognition!'36

The oppositional narrative pushed back against Marxist science to positively embrace the utopianism of dissenting traditions and place ethics at the heart of socialism. John Bruce Glasier's stirring account is an early example. Glasier contrasted the love, faith and noble sacrifice he felt characteristic of socialism with the egotism and ruthlessness of capitalism, openly treating socialism as a social Gospel. Bax was mistaken: socialism promised the attainment of the 'kingdom of man' won through moral courage. It was part of 'the great counterblast of martyrdom, revolt, romance, yea, of common life affections and sacrifice' against 'history's long chronicle of man's selfishness and brutality, man's inhumanity to man'.37

In the post-war period, variations on this narrative helped drive a wedge between socialism and its bureaucratic manifestations. Isaac Deutscher once remarked that in the hands of former communists, the baby was usually lost with the bathwater: having 'set out to defend the ideals of socialism ... the heretic goes on to break with communism itself ${ }^{38}$ Yet other twentieth-century scholars presented utopian narratives to resurrect currents lost to Marxist orthodoxy. Warren Sylvester Smith's The London Heretics (1967) ${ }^{39}$ highlighted the spiritual dimensions of positivist, secular socialism to place scientific socialism on the margins of socialist history and re-position ethical socialism at its heart. ${ }^{40}$ Smith's defence of the 'heretics' corrected what Victor Kiernan later characterised as Marxism's neglect of the mainsprings of 'the will to socialism', namely 'Utopian fancies' and 'the ideas and ideals'

\footnotetext{
${ }^{36}$ Ernest Belfort Bax, The Rise and Fall of the Anabaptists (1903; repr. New York: Kelley, 1970) ch. 11 https://www.marxists.org/archive/bax/1903/anabaptists/index.htm (accessed April 11, 2019)

${ }^{37}$ John Bruce Glasier, The Meaning of Socialism (London: National Labour Press, 1920), 8.

${ }^{38}$ Isaac Deutscher, Heretics and Renegades (London: Jonathan Cape, 1969), pp. 14-15.

${ }^{39}$ Warren Sylvester Smith, The London Heretics 1870-1914 (London: Constable, 1967).

${ }^{40}$ On British ethical socialism see Norman Dennis and A.H. Halsey, English Ethical Socialism: Thomas More to R.H. Tawney (Oxford: Clarendon Press, 1988); Jon Cruddas and Jonathan Rutherford, 'Ethical Socialism', Soundings, vol. 44 (2010): 10-21.
} 
and 'emotional wants left by religion'. ${ }^{41}$ It also mapped scientific socialism to violent revolution. Dismissing the opposition that Kiernan, like Kautsky, saw between reformism and 'cataclysmic transition ${ }^{42}$ Smith championed the pacific revolution the positivists' achieved: they 'changed the established mind of the Western world', ${ }^{43}$ permanently altering 'the nature of orthodoxy'. ${ }^{44}$ Max Nomad's Political Heretics (1963), a history of socialist theory and practice from Thomas More to Mao, likewise rescued heresy from materialist history but generalised it as a form of rebellion: 'the history of human progress' was written 'in terms of revolts against the status quo prevailing at any given time'. ${ }^{45}$ History showed that rebellion had only resulted in the substitution of one lot of 'crooks and grafters' for another. ${ }^{46}$ Still Nomad advocated continual heretical disruption and transgression. In the early 1960s it seemed that heresy was the only possible response to the depressing choice between Leninist and free market orthodoxies. In this sense, it represented a utopian hope of an alternative.

These narratives heresy and utopianism have reverberated in contemporary analyses of anarchism, too. The roots can be traced to the tensions between Marxists and anarchists that grew during the years of the Second International (1889-1914). Already derided by Engels as 'those people' who 'disrupt every workingmen's movement', ${ }^{47}$ the anarchists became the primary target of the anti-utopian attack. In the late 1890s Ernest Zenker, a Social Democrat, published one of the earliest histories of anarchism. This depicted anarchists as utopians and heretics in equal measure. His narrative was based on a complex interweaving of productive dissent with a critique of utopian excess. It cast anarchists as latter-day heretics,

\footnotetext{
${ }^{41}$ Victor Kiernan, 'Socialism, The Prophetic Memory' in The Concept of Socialism, ed. Bhirkhu Parekh (London: Croom Helm, 1975), 36.

${ }^{42}$ Ibid., 36.

${ }^{43}$ Smith, London Heretics, 25.

${ }^{44}$ Ibid., 26.

${ }^{45}$ Max Nomad, Political Heretics (Ann Arbor: University of Michigan Press, 1963), 1.

${ }^{46}$ Ibid., 2

${ }^{47}$ Frederick Engels, 'Marx, Heinrich Karl', in Karl Marx and Frederick Engels Collected Works (1868; repr. London: Lawrence and Wishart, 1990), vol. 27: 340.
} 
valiant but deluded fanatics, wedded to a worthy social vision that was always unattainable and consequently bred violence through frustration.

\section{The Straw Man: Anarchism as heresy}

The publication of E.V. Zenker's Anarchism; A Criticism and History of the Anarchist Theory, ${ }^{48}$ James Joll's The Anarchists ${ }^{49}$ and Saul Newman's From Bakunin to Lacan ${ }^{50}$ spans just over a hundred years of anarchist history and politics. The connections between these books are oblique. Neither Joll nor Newman appears to have consulted Zenker. The coincidence of Joll's endorsement of Zenker's main findings is best explained by his regard for Norman Cohn's Pursuit of the Millennium. ${ }^{51}$ Newman used poststructuralism to develop his critical reading of nineteenth-century European anarchist thought. Joll is not cited in his bibliography. Yet these accounts of late nineteenth-century European anarchism are remarkably consistent. When we look at each in turn, it appears that Zenker, Joll and Newman use similar theoretical markers to construct anarchism and that they offer strikingly similar assessments of anarchist politics. Parkin defines a straw man as a process through which a "philosophical position is transformed into a simplified agenda for some sort of problematic policy'; where political philosophy 'is 'reduced to a practical problem to which the creator of the straw man usually has a philosophical answer'. In Zenker, Joll and Newman's constructions, the heretical, utopian aspects of anarchism reveal a conception of corrupted humanity which reduces to a naïve, yet violent call for redemption.

\footnotetext{
${ }^{48}$ E.V. Zenker, Anarchism; A Criticism and History of the Anarchist Theory (New York and London: Knickerbocker Press, 1897), originally published as Der Anarchismus. Kritische Geschichte der anarchistischen Theorie, (Jena: G. Fischer, 1895).

${ }^{49}$ James Joll, The Anarchists (London: Eyre and Spottiswoode, 1964), $2^{\text {nd }}$ edn. (London: Methuen, 1979). References are from the 1964 edn.

${ }^{50}$ Saul Newman, From Bakunin to Lacan: Anti-Authoritarianism and the Dislocation of Power (Lanham: Lexington Books, 2001).

${ }^{51}$ Norman Cohn, The Pursuit of the Millennium (1957; repr. London: Granada 1984).
} 


\section{Three Anarchist Histories}

The starting point for Zenker's critical account of anarchism was that it was neither entirely absurd nor pathological. Anarchism was 'an idea' which contained all the 'failings and dangers' that extended from theorising. Yet its advocates were 'almost entirely men of great natural gifts, who rank high both intellectually and morally'. ${ }^{52}$ Similarly, while he believed that anarchists possessed a 'superficial' understanding of the causes of 'pauperism, misery, and crime', he believed that their determination to remove these abuses was sincere and motivated by a laudable commitment to equality. ${ }^{53}$

Depicting anarchists as proponents of liberty, Zenker argued that the distinctive feature of anarchism was the disavowal of "compulsory organisation in the social relationships of individuals'. Anarchy was 'the perfect self-government of the individual, and consequently, the absence of any kind of external government' ${ }^{54}$ Believing that the recognition of individual freedom could only occur in sociological contexts where 'the actual process of setting the individual free in his moral and political relationships' was underway, Zenker also concluded that anarchism was a modern doctrine. ${ }^{55}$ Yet even while the conditions for anarchism's expression were 'not to be found in the whole of antiquity, and still less in the middle ages', it was possible to trace its conceptual roots to Millennialism.

Keen to show the tradition played out theoretically and in practice, Zenker was concerned to avoid doing 'violence to history'. His solution was to use the 'revolt against authority' to infer the 'Anarchist influences' at work in the Reformation. Müntzer was not part of Zenker's story. Instead he focused on the thirteenth-century Amalricians sometimes called the Brothers and Sisters of the Free Spirit; the Bohemian followers of Peter of Chelčický, active in the 1450s and the Anabaptist sect of the Free Brothers who congregated

\footnotetext{
${ }^{52}$ Zenker, Anarchism, 7.

${ }^{53}$ Ibid., 31.

54 Ibid., 3-4.

55 Ibid., 10.
} 
in Zurich in the 1560s. The anarchism of these movements came from different roots and took a variety of forms. The Amalricians 'preached community of goods' and also 'of women' and 'a perfect equality' that rejected 'every form of authority'. Their anarchism extended from Panthesism: 'Since God is everything and everywhere ... it follows that the will of man is also the will of God' and that 'every limitation of man is objectionable'. 56 Chelčický was described as a communist and egalitarian who taught that the state was 'sinful' and the 'outcome of the Evil one' responsible for creating 'the inequality of property, rank, and place' and, indeed, all compulsion. ${ }^{57}$ The Free Brothers were also communist: they held 'wives and property in common' and considered themselves free from all laws, so refused to pay taxes or tithes or perform 'duties of service or serfdom'. ${ }^{58}$

For Zenker, the unifying thread in these movements was the myth of the Golden Age 'where men followed merely the laws of reason (Morality, God, or Nature, or whatever else it is called), and needed no laws or punishments to tell them to do right and avoid wrong'. ${ }^{5}$ The same idea was embedded in 'Graeco-Roman and Judaic-Christian' religion, though Zenker concentrated on the connections with the latter, linking Millennialism to " the Fall"” and the attendant idea of recovery 'in a better world', 'as Eden-like as the first state of man, and eternal'. His thesis was that this myth had become heretical over time. Citing Kautsky to support his history, Zenker endorsed Engels' labelling of Christianity as a proletarian movement that had gradually lost touch with the poor and the oppressed, turning against its natural constituents to defend wealth, power and privilege. In Zenker's long view, the myth was subsequently rationalised to become a mainstay of social contract theory. ${ }^{60}$ Here, it worked in two ways, shaping both an anti-absolutist, anti-Hobbesian view of society and an idea of revolutionary transformation. Zenker found the historical meeting point of this

\footnotetext{
${ }^{56}$ Ibid., 11.

${ }^{57}$ Ibid., 12-13.

58 Ibid., 13.

${ }^{59}$ Ibid., 13-14.

${ }^{60}$ Ibid., 15.
} 
version of the myth in the French Revolution. Philosophically, the myth was socialised as anarchy, formulated as the 'primeval' condition of society, a 'Paradise without laws, existing before civilisation' and a 'normal state of mankind' ${ }^{61}$ In practice, it emboldened efforts to realise utopia, here conceived as a world without masters and without oppression. In this guise, he argued, anarchy constituted 'the programme of the French Revolution', ${ }^{62}$ driving the most repressive, terroristic imposition of law.

Zenker acknowledged that anarchists were stalwart opponents of Jacobins and that Jacobins were equally indisposed to anarchists, usually denouncing them as individualists. Nevertheless, examining post-revolutionary secret societies, notably the Carbonari, he argued that Jacobin violence, conspiracy and dictatorship were part and parcel of the anarchist Millenarian tradition: 'though the fundamental dogma of Anarchism is rejected, we notice a step forward in the extension of the Anarchist idea'. In other words, the Carbonari, bearers of Jacobinism, adopted anarchism as a tactic and supported 'every effort which, by encouraging individualism to an unlimited extent, is hostile to the union of society as such. Thus we find individual Carbonarists with pronounced Anarchist views and tendencies' ${ }^{63}$

James Joll's account of anarchism was also structured by a two-pronged history, its stance indicated by the title of the opening chapter, 'Heresy and Reason'. Turning first to the heresies, which he defined broadly as revolts 'against established authority', ${ }^{64}$ Joll distinguished the religious from the doctrinal. Both involved the critique of 'the world's values', but the former tendencies strove for the purification of belief rather than social change. This distinction opened the way to a discussion of religious dissent in the Middle Ages where it turned out to be less solid than Joll implied. First detecting signs of religious heresy in 'utopian and quietist beliefs' and 'extreme ... anarchist individualist non-

\footnotetext{
${ }^{61}$ Ibid., 16; 17.

62 Ibid., 15.

${ }^{63}$ Ibid., 22.

${ }^{64}$ Joll, The Anarchists, 17.
} 
conformity, ${ }^{65}$ Joll then also found religious dissent in movements involved in agitation for social change. Three Anabaptist 'prophets' - Thomas Müntzer, John of Leyden and Jan Mathys - were central figures in Joll's anarchist pre-history.

Borrowing from Cohn's history, Joll adapted his thesis. One of a number of leading historians interested in the sociology of Millenarian movements and its moderns manifestations, ${ }^{66}$ Cohn had identified Müntzer as Marxism’s exemplary forerunner, just as Kautsky had done, but he also disputed the accuracy of communist history, dryly noting Müntzer's 'general indifference to the material welfare of the poor'. Cohn's view, that Anabaptists and Marxists were hewn from the same stone, followed from his assessment of Müntzer as 'a propheta obsessed by eschatological phantasies which he attempted to translate into reality by exploiting social discontent ${ }^{67}$ This was the magnetic force that led Marxists 'to claim him as their own'. 68

Joll's rendering of the psychological legacy of Reformation history used Cohn's template but substituted anarchism for Marxism and also re-specified the triggers: Müntzer's 'genuine attempt at social revolution' made him equally a hero for Marxists and anarchists, but the anarchists were linked 'emotionally, if not doctrinally with the extreme heretics of the earlier centuries'. ${ }^{69}$ They were drawn especially to 'the revolutionary violence of the language in which [Müntzer] expressed himself' ${ }^{70}$ Joll identified John of Leyden as another

\footnotetext{
65 Ibid., 19.

${ }^{66}$ See Yonina Talmon, 'Pursuit of the Millennium: The Relation Between Religious and Social Change', European Journal of Sociology 3 (1962) :125-148.

${ }^{67}$ Cohn, Pursuit of the Millennium, 251. A 'propheta' was a man with prestige but no official authority who preached to the common people. Cohn's finding is challenged by Michael Baylor who argues both that the reformers 'came to articulate social and economic grievances' and that 'there is scant evidence that Müntzer or other leaders of the uprising were motivated by specifically millenarian dreams of a perfect society'. Introduction to The Radical Reformation (Cambridge: Cambridge University Press, 1991), xviii-xix.

${ }^{68}$ Cohn, Pursuit of the Millennium, 251.

${ }^{69}$ Joll, The Anarchists, 27.

${ }^{70}$ Ibid., 23.
} 
proto-anarchist: his 'rule in Münster exemplified only the blindest, maddest and most negative aspects of anarchistic fanaticism and violence'. ${ }^{71}$

The second strand of Joll's history, 'Reason', gave the anarchist heretical antiauthoritarianism a humanist slant, positioning anarchism as one of the ideologies to emerge in the aftermath of the French Revolution and essentially as a product of eighteenth-century political philosophy. Wary of suggesting that anarchism was philosophically grounded, Joll suggested that the tension between religious, heretical influences and rational doctrine was always present. It was possible to find anarchist philosophers and, like Zenker, Joll identified William Godwin as a genuine anarchist, responsible for elaborating 'the most complete and worked-out statement of rational anarchist belief ever attempted'. ${ }^{72}$ But it was important not to overstate his influence. Anarchists were prone to cherry-pick ideas to justify their actions rather than rigorously develop political theory to support their political intuitions. So when anarchism emerged in the mid and late nineteenth centuries, its exponents demonstrated a faith in progress and a belief in the 'natural goodness of man', views characteristic of Enlightenment philosophy, but little else. The 'basis for all anarchist thought' was the 'fundamental idea that man is by nature good and that it is the institutions that corrupt him'. ${ }^{73}$ Moreover, he contended that the anarchists took this insight from French utopians, not Godwin. Thus the distinctive twist they added was the rejection of the 'spartan discipline' that Rousseau and his acolytes recommended. Their critique was guided by emotion not

\footnotetext{
${ }^{71}$ Joll overlooked discussions of Reformation history by Peter Kropotkin and Rudolf Rocker. Kropotkin identified a libertarian spirit in the Albigensians, Moravian Brotherhood and Anabaptists. Ethics: Origins and Development (1924; repr. New York/London: Benjamin Blom 1968) p. 134; Rocker focused on the egalitarian aspirations of would-be reformers (Wycliffe, Huss, Chelčicky) and the violent eclipse of this movement by Protestant absolutists (Luther, Calvin and the Swedish king, Gustavus I). Nationalism and Culture (1947; repr. St. Paul, Minnesota: Michal E. Coughlin, 1978) ch. 6.

${ }^{72}$ Joll, The Anarchists, 31.

${ }^{73}$ Ibid., 30.
} 
reason. ${ }^{74}$ Anarchists were 'temperamentally' opposed to 'intense communal regulation of the individual's activities'. ${ }^{75}$

Joll's analysis of heresy suggested that anarchists were utopians of a special type, more interested in the 'act of revolt' than 'the nature of the post-revolutionary world'. Anarchists were heretical visionaries not imaginative piecemeal engineers and their plans were hazy and unpolished. Thus Joll agreed with Zenker about the utopian qualities of heretical anarchism but, perhaps because he borrowed from Cohn, who stressed the analogy with totalitarian movements, his reinforcement of Zenker's finding also hinted that heresy and utopianism were oppressive fantasies: ${ }^{.7}$

Movements of this kind based their demand for social changes on a belief in the immediate possibility of the millennium - a combination of the Second Coming and a return to the Golden Age of the Garden of Eden before the Fall ... Most of these sects ... met the fate that awaited the utopian groups of later centuries. The leader would become increasingly megalomaniac; the group would split into rival movements; or else it would provoke the resentment of the authorities ... There was simultaneously a sense of desperation, a feeling that there was something hopelessly wrong with the world, and at the same time there was a firm belief in the possibility of putting things right, if only the institutions which hindered the doing of God's will could be destroyed. ${ }^{77}$

\footnotetext{
74 The finding dovetailed with Eric Hobsbawm's assessment of anarchism and Spanish anarchism in particular. The irrationalist thesis is outlined and rejected in Jerome R. Mintz, The Anarchists of Casas Viejas (Chicago: Chicago University Press, 1982), 5-6; 271-276.

${ }^{75}$ Joll, The Anarchists, 29.

${ }^{76}$ See Russell Jacoby, Picture Imperfect: Utopian Thought for an Anti-Utopian Age (New York: Columbia, 2005), 49-51.

${ }^{77}$ Joll, The Anarchists, 20-21.
} 
In Newman's work, Zenker's and Joll's histories of anarchism are distilled into a poststructuralist critique of nineteenth-century anarchist Enlightenment thinking. Newman has no interest in anarchism's heretical roots and, moreover, suggests that Joll was wrong to argue that anarchism was an emotional rather than a reasoned philosophical response to domination and exploitation. Yet while Newman's novel theoretical framing detaches anarchism from heresy and puts Reason is its heart, he presents an equivalent account of the Fall and uses this to develop a critique of anarchist utopianism which reinforces their findings.

Newman roots utopianism in the analysis of anarchism's theoretical premises. First: 'Anarchism is based on a specific notion of human essence' and a belief in 'natural human morality'. Second, this rosy view underpins a distinction that anarchists make between 'natural' and 'artificial' authority and the idea that 'external power stultifies the development of humanity's innate moral characteristics and intellectual capacities'. ${ }^{78}$ Third, arguing that 'man is born with essential moral and rational capacities ${ }^{79}$ and that human essence remains uncorrupted by the external power to which individuals are subjected in the state, anarchists adopt a 'harmony model of society' ${ }^{80}$ Newman's general account follows: 'Anarchist political philosophy is, therefore, based on an essentially optimistic conception of human nature: if individuals can have a natural tendency to get on well together, then there is no need for the existence of a state to arbitrate between them'. ${ }^{81}$

Newman reconceptualised the dissenting qualities that Zenker and Joll found in anarchism by presenting anarchism as the mirror image of both traditional theology and eighteenth-century political theory. Proceeding from what he labels the 'Manichean division between ... state and society' that pits "“living sociability" against the state', anarchism

\footnotetext{
${ }_{78}^{78}$ Newman, From Bakunin to Lacan, 38.

${ }^{79}$ Ibid., 41.

${ }^{80}$ Ibid., 43.

${ }^{81}$ Ibid., 42.
} 
created 'an essential, moral opposition between society and the state, between humanity and power; the morality and rationality immanent in natural human society comes into conflict with the fundamental irrationality and immorality of the state' ${ }^{82}$ Because anarchists saw the state as the "wheel upon which man is broken, the ... alter upon which human freedom is sacrificed' they rejected the proposals that social contract theorists advanced. Nevertheless they followed Enlightenment humanists in seeking 'to restore man to his rightful place at the center of the philosophical universe'. ${ }^{83}$

Newman avoided the language of heresy and, distancing himself from the nineteenthcentury Marxist scientific critique of utopianism, argued that traditional anarchism was in fact not so different from Marxism. Anarchism's leading advocates, notably Bakunin and Kropotkin, also recruited science to advance anarchy. Both believed that 'that there was a rational logic at work in society and history, a logic that was only intelligible through science'. Bakunin found this logic in "'immutable" natural laws'. Kropotkin saw it in 'natural sociability' and the "“permanent instinct" towards co-operation'. ${ }^{84}$ Strangely, this final twist brought his analysis in line with Zenker's and Joll's. Representing anarchism as an 'Enlightenment-based radical political philosophy', Newman concluded that anarchism was an ideology rooted in the recovery of perfection. Anarchist revolution, Newman observed 'would involve a destruction of authority, but in this destruction there would be at the same time, the restoration of a rational social order. In other words, the anarchist transgression of authority is inseparable from a "return" to a lost social fullness'. ${ }^{85}$ Joll and Zenker were mistaken in thinking that the anarchist drive was irrational. But they were right to argue that anarchism promoted a form of blueprint utopianism. ${ }^{86}$ Describing his own position as anti-

\footnotetext{
82 Ibid., 47.

${ }^{83}$ Ibid., 39.

${ }^{84}$ Saul Newman, 'Anarchism, utopianism and the politics of emancipation' in Anarchism and Utopianism, ed. Laurence Davis and Ruth Kinna (Manchester: Manchester University Press, 2009), 213.

${ }^{85}$ Ibid., p. 213.

${ }^{86}$ Saul Newman, The Politics of Postanarchism (Edinburgh: Edinburgh University Press, 2011), 66-7.
} 
utopian utopian, Newman resurrected the anti-anarchist tropes implicit in the historians' critique of heretical communism and by closing the gap between anarchist utopianism and Marxist science, categorising both ideologies as 'utopian scientism'.

\section{Anarchist Heresy and Utopianism}

Anarchism has no singular or agreed response to the critique of utopianism and heresy. In this last section I look at just two rejoinders: Martin Buber's conception anarchist utopianism and Bakunin's defence of heresy. In different ways, both challenge the central tenet of the straw man thesis, namely, the idea that anarchism is a restorative doctrine constructed around an idea of perfection which has in turn been shaped by an idea of the Fall.

Buber's analysis anarchist utopianism relies on a distinction between two forms of eschatology, one he calls 'apocalyptic' and the other 'prophetic'. Not unlike Zenker and Joll, Buber argues that both forms were 'converted into Utopia' in the course of the French Revolution. Secularised, the apocalyptic version is linked to a 'necessitarian' course of action whereas prophetic eschatology describes a voluntarist impulse. Apocalyptic eschatology is a 'redemptive process' which 'in all its details' is 'fixed from everlasting'. The redeemed 'are only used as tools, though what is immutably fixed may yet be "unveiled" to them, revealed, and they be assigned their function'. In contrast, prophetic 'sees every person addressed by it as endowed, in a degree not to be determined beforehand, with the power to participate in decisions and deeds in the preparing of Redemption'. ${ }^{87}$

Re-purposing Engels' typology of socialism utopian and scientific, Buber contended that Marxism veered strongly towards the apocalyptic while the prophetic was most evident in forms of socialism that Marxists dubbed 'utopian': in common with early nineteenthcentury utopianism, anarchism gave greater weight to the prophetic than the apocalyptic. For

\footnotetext{
${ }^{87}$ Martin Buber, Paths in Utopia, trans. R.F.C. Hull (1949; repr. Boston: Beacon Press, 1958), 10.
} 
Buber, the bias indicated that the antagonism created in late nineteenth-century socialism by the championing of 'science' underpinned two starkly contrary views about the means and ends of socialist change.

Turning to Marxist theory, Buber detected a 'yawning chasm' between the 'road to Revolution', and the socialist transformation 'to be consummated sometime in the future - no one knows how long after the final victory of the Revolution'. While the materialist conception of history outlined a process of 'far-reaching centralization that permits no individual features and no individual initiative', scientific anti-utopian polemics simultaneously discouraged reflection on the realisation of socialist principles. ${ }^{88}$ When Buber explored the prophetic eschatology of non-Marxist "utopian"" socialism, he found a completely different approach: a desire to make 'means commensurate with ... ends'. The utopianism that matched prophetic eschatology, which he branded 'organic planning, ${ }^{89}$ left the scientific analysis of the dynamics of 'history' to one side, preferring to investigate diverse, contradictory social trends with a view to encouraging actions designed either to advance or inhibit them. Prophetic utopians concentrated on the 'here and now', 'the space now possible for the thing for which we are striving, so that it may come to fulfilment then'. Flatly contradicting post-war narratives that tied anarchism to notions of natural law, the Fall and revolutionary recovery, Buber asserted that prophetic utopianism amounted to a rejection of the idea of the 'post-revolutionary leap'. 90

While Buber's idea of anarchist prophetic utopianism corresponded with an antinecessitarian idea of heresy of choosing, Bakunin's explicit defence of heresy detached anarchism from all forms of perfectionism. In Federalism, Socialism and Antitheologism ${ }^{91}$ he

\footnotetext{
${ }^{88}$ The argument had been put forcefully by Gustav Landauer, whose work Buber championed, in For Socialism, trans. David J. Parent (1911; repr. St Louis: Telos Press, 1978).

${ }^{89}$ Buber, Paths in Utopia, p. 11

${ }^{90}$ Ibid., 13.

${ }^{91}$ Michel Bakounine, Fédéralisme, Socialisme et Antithéologisme, Oeuvres vol. 1 (1895 ; Paris : P.V. Stock, 1972).
} 
advanced a sustained attack on 'political theology', linking this to the separation of mind from matter and the denigration of real life measured by the pure standards of faith, thought or philosophy. Part of his explanation consisted in his re-telling the Genesis story. In his version the departure from Eden was an escape, not an ejection. God had imprisoned Adam and Eve. He was a despot, comparable to Blue Beard who killed the wives who flouted his prohibition on entering the underground chamber. ${ }^{92}$ Bakunin's reversal contained a strong anti-authoritarian message: God's instruction to Adam and Eve, not to eat the fruit of the 'tree of science', was a form of enslavement for they were given no reason not to do so and were simply obliged to follow the command. In reversing the logic of political theology, he coupled the rejection of divine authority with active disobedience and taught that noncompliance was the saving of humanity. Compared to the traditional story that legitimised humiliating slavery, Bakunin's anarchist account held out the promise of emancipation and deliverance, but as action not social condition. ${ }^{93}$ There was no perfect freedom in Eden for Adam and Eve to recover.

Bakunin spelt out the political implications of his conception of political theology in a blistering critique of Giuseppe Mazzini, shortly after the crushing of the Paris Commune in $1871 .{ }^{94}$ Mazzini had condemned the Commune describing the Communards as 'egoists'. Bakunin's counter was to argue that Mazzini's political vision was absolutist and 'paralyzed or at least warped by the exclusive and jealous influence of the divine phantom'. ${ }^{95}$ Mazzini was a proponent of a 'new religion' of

\footnotetext{
92 Bakunin's account calls early Church critiques of Gnosticism to mind, though he shows little interest the finer theological and philosophical issues. For a discussion of the Demiurge and Marcion of Sinope see Gerhard May, 'Marcion in Contemporary Views: Results and Open Questions' The Second Century: A Journal of Early Christian Studies vol. 6 (1987), 129-151.

${ }^{93}$ Bakounine, Fédéralisme, Socialisme et Antithéologisme, 179.

${ }^{94}$ For the context, and a sceptical view of Bakunin's motives, see T.R. Ravindranathan, 'The Paris Commune and the First International in Italy: Republicanism versus Socialism, 1871-1872', The International History Review II (1981): 482-516.

${ }^{95}$ M. Bakounine, De Mazzini et L'Internationale (Neuchatel : Commission de Propagande Socialiste, 1871), International Institute of Social History Bakunin papers, An 24, 48. I have used the translation into English by
} 
humanity. This was to be imposed 'on Italy first and then, by means of Italy duly educated,- - that is, muzzled and emasculated,- - on all other countries'. It was based on unity rather than obedience, but it still brooked no dissent. Mazzini simply had no reason 'to question the needs, tendencies, and aspirations of Italy and of other countries' because his vision had 'been revealed ... from on high ... through the false prism of divinity'. ${ }^{96}$ In short, Mazzini was a political theologian, as all-consumed by a desire to save humanity as any Pope, and similarly requiring compliance from those his perfect condition was designed to save. Comparing Mazzini's love of the people to Abraham's love of Isaac, Bakunin argued that he was as equally willing to sacrifice it. Bakunin continued: 'he who serves this God must sacrifice everything to him ... he who loves God cannot really love anything else in the world. He must detest the world; and if ... he wishes to love it, it still must be only for the glory of God, in order to transform the world into a stepping-stone to the divine glory. ${ }^{97}$

In a provocation designed to ridicule Mazzini's sense of divine purpose and attack his condemnation of the Commune, Bakunin openly linked the anarchist rejection of authority to Satanism and heresy, claiming inheritance from thirteenthcentury Spiritual Franciscans:

According to the Mazzinian as well as the Christian doctrine, Evil is the Satanic revolt of man against divine authority, a revolt in which we, on the contrary, see the fruitful germ of all human emancipations. As the Fraticelli of Bohemia in the fourteenth century, the revolutionary Socialists recognize each other today by these words: In the name of him to whom wrong has been done, hail! Only the

Sarah E. Holmes serialised in Liberty 1886 and 1887 at https://www.libertarian-labyrinth.org/bakuninlibrary/the-political-theology-of-mazzini-and-the-international/ (accessed April 11, 2019).

${ }^{96}$ Bakunin De Mazzini et L'Internationale, 58-9. Emphasis original.

${ }^{97}$ Ibid., 48. 
Satan, the conquered but not pacified rebel, of today, is called the Commune of Paris. It is easy to see why all the Christian and Mazzinian theologians, their masters, the Pope and Mazzini, at their head, should have excommunicated the rising of the heroic Commune. This was at last the audacious realization of the Satanic myth, a revolt against God; and today as always the two opposing parties are ranged, the one under the standard of Satan or of liberty, the other under the divine banner of authority. What we call liberty, Mazzini calls egoism; what constitutes in our view the ideal sanction of all slavery, the prostration of man before God and before the authority of that State-Church which, if one is to believe Mazzini, is his permanent revelation on earth, he calls supreme virtue. ${ }^{98}$

In common with other nineteenth-century Romantic Satanists, Bakunin claimed the heretical freedom to defy theologism and resist all systems designed to bring humanity to perfection. ${ }^{99}$ This critique of theologism pointed to the patterning of social relations by the diverse practices and ideals embedded in everyday life. Bakunin included 'religion' and 'faith' in these practices, arguing that beliefs were expressed differently in ordinary existence than they were in abstract philosophy or theology. Here, religion and faith were defined by the desire to impose new order. In the everyday, they described the constant and profound practical aspiration to realise a better life. Christ had had faith, Bakunin argued. Similarly, the people was 'naturally religious'. So enduring poverty and enslavement, the people strove for freedom with a 'religious' commitment that was shaped by solidarity and a distrust of privilege. Evoking Proudhon, Bakunin also described 'religion' as an instinct towards justice

\footnotetext{
${ }^{98}$ Ibid., 56-57. Emphasis original.

${ }^{99}$ See Ruben van Luijk, 'Sex, Science, and Liberty: The Resurrection of Satan in Nineteenth-Century (Counter) Culture' in The Devil's Party: Satanism in Modernity, ed. Per Faxneld and Jesper Aa. Petersen (Oxford: Oxford University press, 2013), 41-52.
} 
and equality or 'instinctive socialism'. ${ }^{100}$ While his concepts were sometimes sketchy and not articulated precisely, the thrust of his argument was that perfection was an ideal that anarchists refused; it was not a loss. However motive forces were described - as religion, faith or instinct - the drive to socialism was never directed towards recovery. Satanic disobedience did not point to a restoration of a pristine condition but to the rejection of that idea.

How tightly Bakunin wanted to tie disobedience to religion or faith is a moot point. ${ }^{101}$ Yet the surprising upshot of Bakunin's antitheologism is that the line between atheistic, anticlerical anarchism and Christian anarchism is finer than sometimes supposed. ${ }^{102}$ Indeed, Bakunin's conjunction of antitheologism with the recognition of 'faith' was found in other expressions of anarchism. The American journal Lucifer the Light-bearer, usually positioned on anarchism's 'individualist' wing, similarly refused alignment with 'any sect, party, "ism" or organisation' while describing its aims in evangelical terms. The editor, Moses Harman, proudly advertised the papers' "'mission", was 'to preach the gospel of discontent'. ${ }^{103}$ In an essay on the Christian Church, Harman also distinguished 'faith' from its permanent institutionalisation. Christianity was 'a sentiment, not an organised reality' whereas the Church, 'organised by Paul and other hierarchs' was intimately linked to capitalism, through the defence of mastership and slavery. ${ }^{104}$ The promotion of faith, through anarchism, was linked to moral principle - justice understood as the belief that all people 'are born free and equal' and that all equally have the right to practice self-government. 'Freedom to advocate the abolition of government of man by man' was far from being won, as the repeated arrest

\footnotetext{
${ }^{100}$ Bakunin 'Contre Mazzini', [1871] Oeuvres complètes, ed. Arthur Lehning, Amsterdam: Institute of Social History, 2000.

${ }^{101}$ For a discussion of the Bakunin's religious beliefs see Rob Knowles, "'Human Light"”: the Mystical Religion of Mikhail Bakunin', The European Legacy 7 no. 1 (2002): 7-24. On Tolstoy's Christian anarchism see Alexandre Christoyannopoulos, Tolstoy's Political Thought (London: Routledge, forthcoming).

${ }^{102}$ For the view that Christian anarchism is a 'peculiar variant' of anarchism see Alexandre Christoyannopoulos, Christian Anarchism: A Political Commentary on the Gospel (Exeter: Imprint Academic, 2010), 5.

103 'The Gospel of Discontent', Lucifer the Light-bearer, April 7, 1897, 108.

${ }^{104}$ Moses Harman 'Socialism and the Christian Church', Lucifer the Light-bearer, March 28, 1907, 53.
} 
and imprisonment of women and men who asserted it made abundantly clear. Like Bakunin, Harman had faith that by constant disobedience this utopian, heretical possibility could still be advanced.

\section{Conclusion}

By showing how narratives about heresy were complicated by constructions of utopia and utopianism in the nineteenth century, I have tried to expose an enduring misreading of anarchism as a form of Millenarianism. Zenker, Joll and Newman contribute to the construction of straw man: anarchism as a naive political theory structured by dreams of restoration and return. As Buber noted, anarchism is utopian in the sense that it seeks to challenge myths of obedience which run counter to self-organisation and self-government. Anarchism rejects the authority of church and state and, as Bakunin argued, political theology. This lends it a heretical quality. But the anarchist embrace of heresy reflects a preference for autonomous choosing. This highlights the seriousness of the anarchists' denial of utopian perfection and commitment to resist orthodoxy. 